\title{
Chemoenzymatic methods in the asymmetric synthesis of $\alpha$-diazosulfoxides
}

\author{
Anita R. Maguire, * Stuart G. Collins, and Alan Ford \\ Department of Chemistry, Analytical and Biological Chemistry Research Facility, University \\ College Cork, Cork, Ireland \\ E-mail: a.maguire@ucc.ie
}

Dedicated to Professor M. Anthony McKervey on his $65^{\text {th }}$ birthday

(received 18 Feb 03; accepted 22 Apr 03; published on the web 01 May 03)

\begin{abstract}
Asymmetric synthesis of the sulfide lactones 12 and $\mathbf{1 3}$ in excellent enantiopurity is achieved by reduction of cyclohexanone derivative $\mathbf{1 0}$ using baker's yeast, followed by acid catalysed cyclisation. The outcome of the yeast reduction is very sensitive to the reaction conditions employed. Transformation of 12 to the $\alpha$-diazosulfoxide 4 ( $\geq 98 \%$ ee) and rhodium acetate catalysed decomposition of this are also described.
\end{abstract}

Keywords: Baker's yeast, dynamic kinetic resolution, $\alpha$-diazosulfoxides

\section{Introduction}

While diazo groups are readily introduced to active methylene positions in $\beta$-dicarbonyl compounds, $\beta$-keto sulfones, $\beta$-keto phosphonates etc., ${ }^{1}$ introduction of a diazo group adjacent to a sulfoxide is generally unsuccessful due to the inherent instability of the $\alpha$-diazosulfoxide moiety. ${ }^{2}$ As $\alpha$-diazosulfoxides are envisaged to have significant potential in stereoselective synthesis, we decided to investigate the reason for this instability with the objective of designing and synthesising stable $\alpha$-diazosulfoxide derivatives. We found that by constraining the conformational mobility of the sulfoxide precursors for example in the bicyclic lactones 1-3, diazo transfer to form stable isolable $\alpha$-diazosulfoxides 4-6 is possible (Scheme 1). ${ }^{3}$

Furthermore, rhodium catalysed decomposition of these derivatives offers a novel synthetic route to $\alpha$-oxo sulfine intermediates which undergo dimerisation to form sterically hindered alkenes, or can be trapped as cycloadducts with dienes as illustrated in Scheme 2 for $\alpha$ diazosulfoxide 5. ${ }^{4}$ Direct evidence for the formation of the key $\alpha$-oxo sulfine intermediate was secured by photolysis in an argon matrix. ${ }^{5}$ This novel route to $\alpha$-oxo sulfines and the resulting sterically hindered dimeric alkenes or the cycloadducts offers considerable synthetic potential; 
accordingly we wished to extend this work to the enantiomerically enriched series of $\alpha$-diazosulfoxides to allow access to the products of rhodium catalysed decomposition in enantioenriched form.<smiles>O=C1C[S]([O-])[C@H]2CCCC[C@H]2O1</smiles><smiles>N=C1C(=O)O[C@@H]2CCCC[C@H]2[S]1[O-]</smiles><smiles>C[C@@]12CCCC[C@H]1OC(=O)C[S]2[O-]</smiles><smiles>N=C1C(=O)O[C@@H]2CCCC[C@H]2[S+]1[O-]</smiles><smiles>CC(=O)O[C@@H]1CCCC[C@@H]1[O-]</smiles>

3<smiles>C[C@]12CCCC[C@H]1OC(=O)C(=N)[C@@H]2[O-]</smiles>

6

\section{Scheme 1}<smiles>N=C1C(=O)O[C@H]2CCCC[C@H]2[S+]1[O-]</smiles>
5

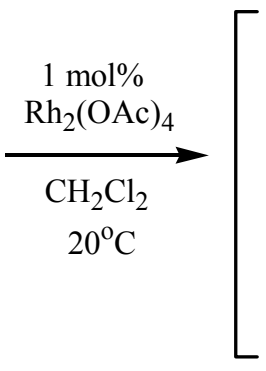

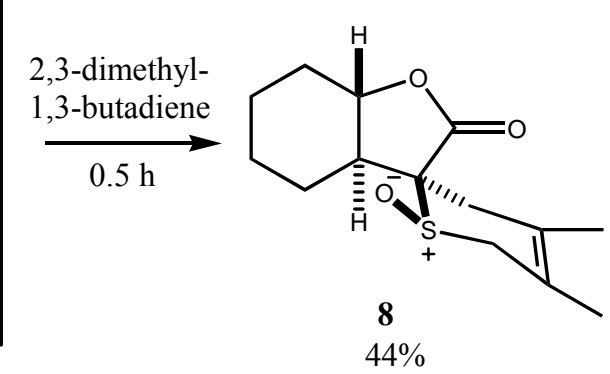

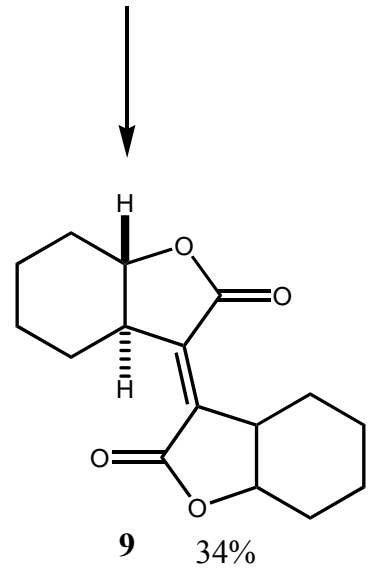




\section{Scheme 2}

Based on our experience in baker's yeast ${ }^{6}$ (Saccharomyces cerevisiae) mediated reduction of cycloalkanones bearing sulfur substituents at the $\alpha$-position, ${ }^{7}$ we envisaged that this methodology could be employed for the asymmetric synthesis of the lactone precursors. We have recently demonstrated that efficient dynamic kinetic resolution of 2benzenesulfonylcyclopentanones and -cyclohexanones can be achieved using baker's yeast, ${ }^{8}$ while Fujisawa and co-workers have reported that analogous 2-phenylthiocycloalkanones also undergo dynamic kinetic resolution on treatment with baker's yeast. ${ }^{9}$ Therefore, we envisaged that yeast mediated reduction of the $\alpha$-thio cyclohexanone 10, followed by ring closure of the resulting hydroxy ester 11 should lead to the lactone 12 (Scheme 3). Prior to this work, Vankar and co-workers had reported that baker's yeast mediated reduction of $\mathbf{1 0}$ leads to the trans-fused lactone 13 in low yield $(\sim 16 \%),{ }^{10}$ but did not furnish details of the enantiopurity or the absolute stereochemistry of the isolated lactone. Based on our experience, we envisaged the cis-fused product should predominate and therefore found this report rather surprising. In this paper we report the asymmetric synthesis of the lactones $\mathbf{1 2}$ and $\mathbf{1 3}$ using this approach and transformation of 12 to the diazosulfoxide $\mathbf{4}$ in excellent enantiomeric purity.

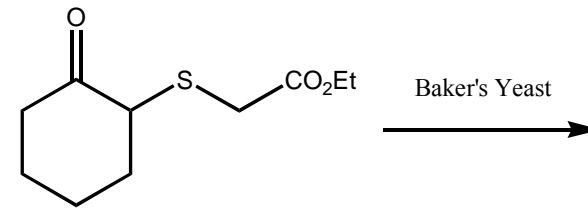

10

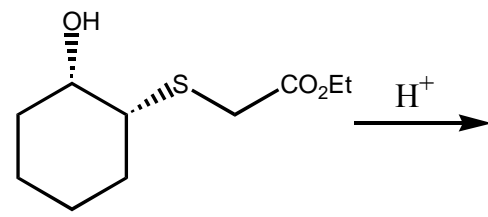

11

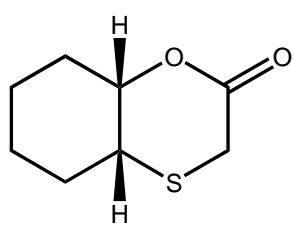

12

Scheme 3

\section{Results and Discussion}

The $\alpha$-thio cyclohexanone $\mathbf{1 0}$ required for investigation of the baker's yeast reduction was readily synthesised from commercially available 2-chlorocyclohexanone as outlined in Scheme 4. Investigation of the reduction of this compound with baker's yeast was explored under a variety of conditions as illustrated in Table 1 . As we have observed in our earlier work ${ }^{7,8}$ the outcome of the reduction, in terms of efficiency and stereoselectivity, is very sensitive to variation of the reduction conditions. ${ }^{11}$ On a small scale, analysis of the hydroxy esters $\mathbf{1 1}$ and 14 is complicated by spontaneous partial cyclisation; therefore it is convenient to cyclise these directly by warming in the presence of $p$-toluenesulfonic acid (tosic acid). For larger scale reactions cyclisation in situ proves not to be reproducible; extensive work showed that the cyclisation is best carried out precisely as described by Vankar. ${ }^{10}$ Heating with tosic acid for longer than 15 minutes leads to extensive decomposition of the lactones $\mathbf{1 2}$ and $\mathbf{1 3 .}$ 
Determination of the efficiency of the reduction, the diastereoselectivity, and the enantiomeric purity of each of $\mathbf{1 2}$ and $\mathbf{1 3}$ is very straightforward using NMR and HPLC analysis. Assignment of the diastereomers by ${ }^{1} \mathrm{H}$ NMR is straightforward, while the absolute stereochemistry of $(5 R, 6 S)-12$ and $(5 S, 6 S)-13$ is assigned on the basis of the well established literature precedent for the enantioselectivity of baker's yeast in the reduction of sulfur substituted ketones. ${ }^{6-8}$
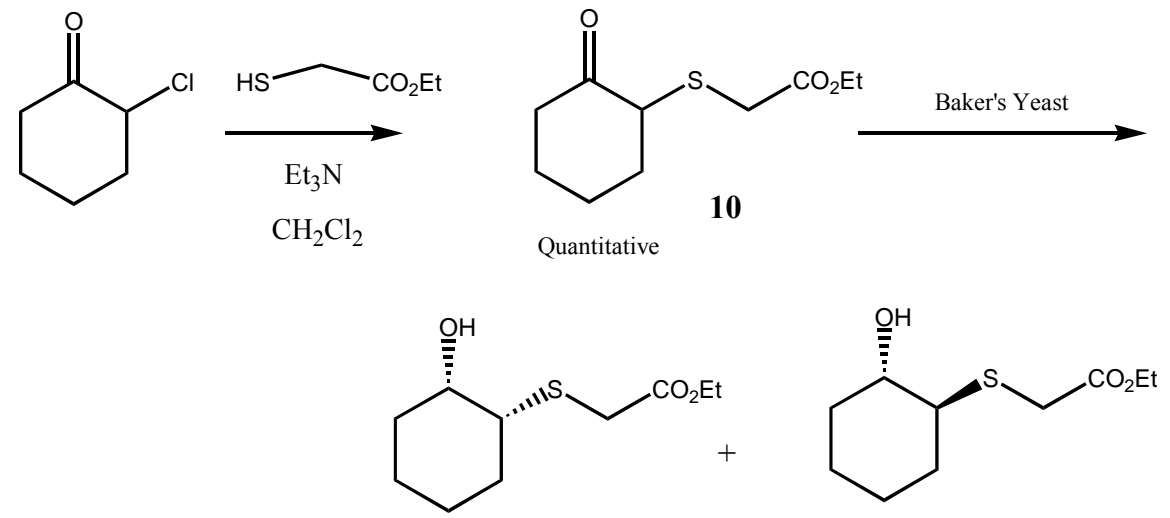

11

14

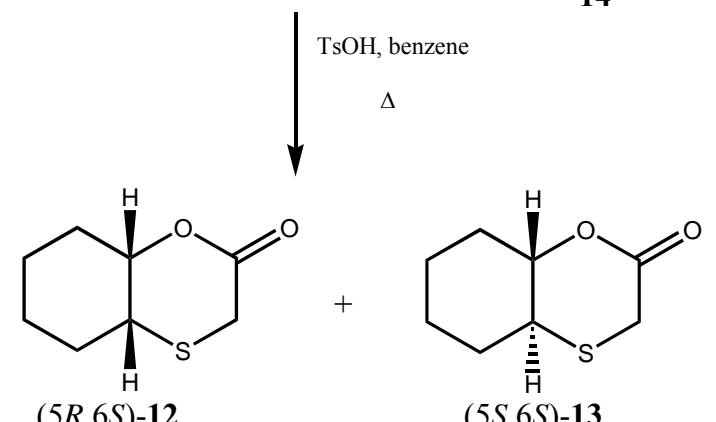

$(5 R, 6 S)-12$

$(5 S, 6 S)-13$

\section{Scheme 4}

As can be seen from Table 1 mixtures of the cis and trans fused lactones $\mathbf{1 2}$ and $\mathbf{1 3}$ were isolated from each of the yeast reductions, indicating that both hydroxy esters $\mathbf{1 1}$ and $\mathbf{1 4}$ were formed in the reactions. ${ }^{12}$ However, the ratio of the products varied considerably indicating that the diastereoselectivity of the yeast reduction is very sensitive to the reaction conditions. Apparently, different yeast alcohol dehydrogenases catalyse the reduction of $2 R-\mathbf{1 0}$ to form $\mathbf{1 1}$ and $2 S-10$ to form 14 and the relative activity of these enzymes is readily influenced by the reaction conditions. Significantly, in our earlier work $^{8}$ on the yeast mediated reduction of 2-benzenesulfonylcyclohexanone only the cis isomer of 2-benzenesulfonylcyclohexanol was isolated with excellent enantiopurity. In this work the dynamic kinetic resolution is less efficient, leading to both the cis and trans substituted products 11 and 14. Similarly, Fujisawa ${ }^{9}$ reported a 9:1 ratio of cis and trans isomers of 2-phenylthiocyclohexanol from the yeast mediated reduction of 2-phenylthiocyclohexanone. Thus, while dynamic kinetic resolution of 2-thiocycloalkanones is possible, it is less diastereoselective than the process with 
2-sulfonylcycloalkanones. This may be due to the decreased acidity of the $\alpha$-hydrogen in the sulfide derivatives compared to the sulfonyl substituted cyclohexanone, which could result in less efficient interconversion of the enantiomers, or it may reflect decreased steric demands of the sulfide substituent relative to the sulfone.

Table 1. Baker's yeast reduction of $\mathbf{1 0}$

\begin{tabular}{|c|c|c|c|c|c|}
\hline \multirow{2}{*}{ Entry } & \multirow{2}{*}{ Conditions $^{\mathrm{a}}$} & \multirow{2}{*}{ Conversion } & \multirow{2}{*}{$\begin{array}{l}\text { Isolated } \\
\text { yield }^{\text {b }}\end{array}$} & \multicolumn{2}{|c|}{ Composition of product } \\
\hline & & & & $\% 12(\mathrm{ee})$ & $\% 13(\mathrm{ee})$ \\
\hline 1 & procedure A & $100 \%$ & $26 \%$ & $78 \%(\geq 98 \%)$ & $22 \%(\geq 98 \%)$ \\
\hline 2 & procedure B & $100 \%$ & $57 \%$ & $59 \%(\geq 98 \%)$ & $41 \%(66 \%)$ \\
\hline 3 & procedure $\mathrm{C}$ & 0 & 一 & & \\
\hline 4 & procedure D & 0 & - & & \\
\hline 5 & $\begin{array}{l}\text { procedure A, inhibited with } \\
\text { allyl alcohol }\end{array}$ & $100 \%$ & $19 \%$ & $77 \%(97 \%)$ & $23 \%(\geq 98 \%)$ \\
\hline 6 & $\begin{array}{l}\text { procedure } A \text {, inhibited with } \\
\text { methyl vinyl ketone }\end{array}$ & $100 \%$ & multiple & roducts & \\
\hline 7 & $\begin{array}{l}\text { procedure } A \text {, inhibited with } \\
\text { ethyl chloroacetate }\end{array}$ & $100 \%$ & multiple & roducts & \\
\hline 8 & $\begin{array}{l}\text { procedure A, inhibited with } \\
\text { ethyl bromoacetate }\end{array}$ & $100 \%$ & multiple & roducts & \\
\hline 9 & $\begin{array}{l}\text { procedure B, inhibited with } \\
\text { allyl alcohol }\end{array}$ & $0 \%$ & - & & \\
\hline 10 & $\begin{array}{l}\text { procedure } \mathrm{A} \text {, higher } \\
\text { substrate concentration, } 24 \mathrm{~h}\end{array}$ & $20 \%$ & n.d. & $87 \%(\geq 98 \%)$ & $13 \%(\geq 98 \%)$ \\
\hline 11 & procedure A, full scale-up & $100 \%$ & $12 \%$ & $78 \%(\geq 98 \%)$ & $22 \%(\geq 98 \%)$ \\
\hline 12 & procedure B scale-up & $100 \%$ & $25 \%$ & $\begin{array}{l}47 \%(\geq 98 \%) \\
4 \%{ }^{\mathrm{c}}(\geq 98 \%)\end{array}$ & $53 \%(76 \%)$ \\
\hline 13 & $\begin{array}{l}\text { procedure B with modified } \\
\text { workup }\end{array}$ & $100 \%$ & $45 \%{ }^{\mathrm{d}}$ & $32 \%{ }^{\mathrm{e}}(\geq 98 \%)$ & $10 \%{ }^{\mathrm{f}}(\geq 98 \%)$ \\
\hline
\end{tabular}

${ }^{a}$ see experimental for details of procedures.

${ }^{\mathrm{b}}$ isolated yield as a mixture of diastereomers. Composition of product and ee's determined by

HPLC; where $\geq 98 \%$ ee is quoted only one enantiomer was detected.

${ }^{c}$ isolated yield of pure 12.

$\mathrm{d}$ isolated yield of pure hydroxy esters 11 and 14 .

e isolated yield of pure $\mathbf{1 2}$ based on the hydroxy esters.

$\mathrm{f}$ isolated yield of pure $\mathbf{1 3}$ based on the hydroxy esters.

Our first experiment followed a modification of a procedure described by Ridley and coworkers $^{13}$ using a very high concentration of yeast (Table 1, procedure A, entry 1). While total 
consumption of the starting material $\mathbf{1 0}$ was observed, isolation of the products from this yeast medium is difficult, resulting in low yields of the hydroxy esters $\mathbf{1 1}$ and $\mathbf{1 4}$ and the resulting lactones 12 and 13. Both lactones displayed excellent enantiomeric purity with only a single enantiomer of each detected by chiral HPLC. As we expected, the cis fused lactone 12 predominates $(78 \%)$. Due to the difficulties in isolation of the products from the concentrated yeast medium, reduction under more dilute conditions following a modification of the procedure described by Seebach ${ }^{14}$ was next attempted (Table 1, entry 2, procedure B). Isolation of the products is easier from the less concentrated medium, resulting in higher yields. However, the diastereoselectivity decreased (59:41 ratio of $\mathbf{1 2}$ and $\mathbf{1 3}$ ) and, while $\mathbf{1 2}$ is still isolated in enantiopure form, the enantiopurity of the trans fused lactone $\mathbf{1 3}$ is significantly reduced. Use of immobilised baker's yeast in hexane ${ }^{11,15}$ and free baker's yeast in ether ${ }^{16}$ (Table 1, entries 3 and 4, procedures $\mathrm{C}$ and $\mathrm{D}$ respectively) were also explored as both of these conditions result in facile product isolation. However, in these reactions only unreacted starting material was recovered.

In order to investigate if the diastereoselectivity of the yeast reduction could be improved, use of inhibitors such as allyl alcohol, methyl vinyl ketone, ethyl chloroacetate and ethyl bromoacetate with procedure A was explored (Table 1, entries 5-8). ${ }^{11}$ The reactions in the presence of methyl vinyl ketone, ethyl chloroacetate and ethyl bromoacetate result in complex mixtures of unidentifiable products, while use of allyl alcohol has little effect on the outcome of the reaction with the stereoselection essentially unchanged. The decrease in yield from $26 \%$ to $19 \%$ is not significant as isolation from the concentrated yeast medium is very difficult. Use of allyl alcohol as an inhibitor under the more dilute conditions (Table 1, entry 9) was also investigated but in this case no reduction is observed.

At this stage it was clear that isolation of the cis fused lactone $\mathbf{1 2}$ in excellent enantiopurity is best achieved using the more dilute conditions of Procedure B. However, to obtain the trans fused lactone 13 with high enantiopurity it seemed necessary to use the more concentrated conditions associated with Procedure A, although this has the disadvantage of difficult product isolation from the biomass. Later experiments (Table 1, entry 13) have indicated that Procedure $\mathrm{B}$ can lead to 13 with $\geq 98 \%$ ee (after purification) when conducted on a larger scale as discussed below. In an attempt to improve the efficiency of Procedure A this biotransformation was repeated using a higher substrate concentration (Table 1, entry 10, $500 \mathrm{mg}$ of $\mathbf{1 0}$ compared to $100 \mathrm{mg}$ in entry 1). After $24 \mathrm{~h}$ of reaction just $20 \%$ conversion was observed. However, the diastereoselectivity of the reduction had improved significantly, presumably associated with the low conversion. Critically the enantioselectivity was unchanged.

Scale-up to synthetically useful reactions was next undertaken. When Procedure A was scaled up to $1 \mathrm{~g}$ of $\mathbf{1 0}$, the stereochemical outcome of the reaction was identical to the small scale reaction (Table 1 , entry $11 \mathrm{cf}$. entry 1 ) but the recovery decreased due to practical difficulties with product isolation from the biomass. When the more dilute procedure $\mathrm{B}$ was scaled up to $1 \mathrm{~g}$ of 10 (Table 1, entry 12, this was conducted in 5 flasks each containing $200 \mathrm{mg}$ and combined for work-up), recovery decreased to $25 \%$ and interestingly the diastereoselectivity of the 
reaction changed with the trans fused lactone $\mathbf{1 3}$ predominating in the product in this instance (Table 1, entry $12 \mathrm{cf}$. entry 2). However, the overall alteration in product ratio of 12:13 from 59:41 to 47:53 is relatively small, and is indicative of the sensitivity of the biotransformation to minor variation in the reaction conditions; the enantioselectivity of the process was essentially unaltered. While the diastereomeric lactones $\mathbf{1 2}$ and $\mathbf{1 3}$ behave very similarly on silica gel, repeated careful chromatography allowed isolation of a pure sample of the enantiomerically pure lactone 12 in 4\% yield from $\mathbf{1 0}$. The decreased product recovery from this scale-up prompted us to explore a modified isolation procedure (Table 1, entry 13) using ether in place of ethyl acetate, and decanting the reaction mixture and ether washings from the biomass, rather than filtering the mixture, provides a much simpler practical method for product isolation and leads to greatly increased recoveries. In this case the intermediate hydroxy esters $\mathbf{1 1}$ and $\mathbf{1 4}$ were purified and recovered in $45 \%$ yield from 10, instead of carrying the crude material through to the lactonisation step, as had been conducted in the previous experiments. Following cyclisation and chromatographic separation of the lactones, the cis fused lactone $\mathbf{1 2}$ was isolated as a single diastereomer in $32 \%$ from the hydroxy esters; only one enantiomer of $\mathbf{1 2}$ could be seen by chiral HPLC. Furthermore, the trans-fused lactone $\mathbf{1 3}$ was isolated from this scale-up of Procedure B following chromatography in 10\% yield in enantiopure form. As HPLC analysis of the product of the earlier reactions, conducted on mixtures of 12 and $\mathbf{1 3}$ without extensive chromatographic purification (Table 1, entries 2 and 12) had indicated reduced enantiopurity of 13, the scale-up was repeated to ensure reproducibility and again led to enantiopure $\mathbf{1 3}$ following chromatography to separate the lactones. One of the most important advantages associated with the use of the more dilute conditions associated with Procedure B is that TLC monitoring of the yeast reduction is possible. In entries 12 and 13 it was found that the reduction takes approximately 6 days for complete consumption of $\mathbf{1 0}$ with addition of fresh yeast and sugar every 2 days.

Therefore, the optimised procedure for the synthesis of the enantiomerically pure lactones 12 and 13 involves use of Procedure B with the ether work-up and chromatographic purification. 

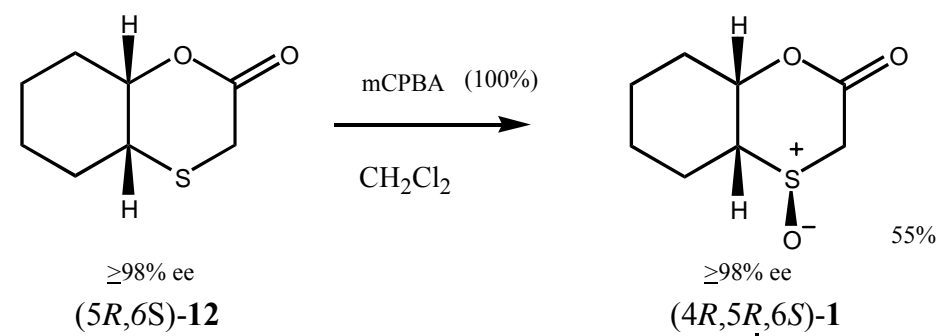

$(4 R, 5 R, 6 S)-1$

$$
\left\lfloor\begin{array}{l}
\mathrm{TsN}_{3} \\
\mathrm{Et}_{3} \mathrm{~N} \\
\mathrm{CH}_{3} \mathrm{CN}
\end{array}\right.
$$

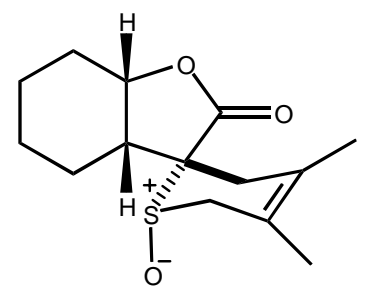

15
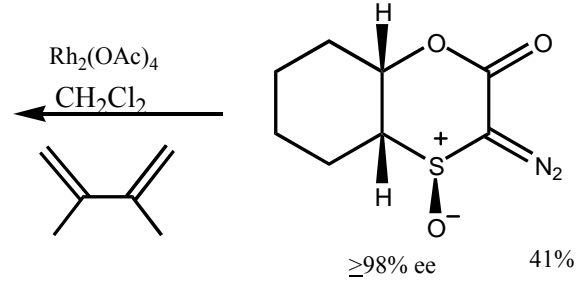

$(4 S, 5 R, 6 S)-4$

\section{Scheme 5}

Transformation of the cis fused lactone 12 ( $\geq 98 \%$ ee) to the sulfoxide was conducted using $m$-CPBA which had been purified before use (Scheme 5). ${ }^{17}$ Oxidation occurs from the exo face only providing the sulfoxide $\mathbf{1}$ as a single diastereomer. As the very polar sulfoxide $\mathbf{1}$ is difficult to purify on silica gel, recrystallisation must be employed for purification, and therefore, it is essential that none of the sulfone is formed. A very short reaction time ( 3 minutes) is necessary to prevent over-oxidation. For this reason, it is more satisfactory to use purified oxidant rather than the commercial product (60-70\%). Chiral HPLC analysis confirms the enantiopurity of the sulfoxide 1 as $\geq 98 \%$ ee. Transformation to the diazosulfoxide 4 was achieved using tosyl azide and triethylamine in acetonitrile and again chiral HPLC demonstrated that $\mathbf{4}$ was obtained in $\geq 98 \%$ ee. Finally rhodium acetate catalysed decomposition of enantiopure 4 in the presence of 2,3-dimethylbutadiene formed the enantiopure cycloadduct 15 which was identical by TLC and NMR to the racemic material we had previously synthesised. ${ }^{4}$

In conclusion, baker's yeast mediated dynamic kinetic resolution of the cyclohexanone derivative 10, followed by cyclisation, can be employed for the asymmetric synthesis of the lactones 12 and 13. The outcome of the biotransformation is very sensitive to the reaction conditions employed and the conditions for isolation of enantiopure $\mathbf{1 2}$ and $\mathbf{1 3}$ have been optimised. Use of this methodology for the asymmetric synthesis of the $\alpha$-diazosulfoxide $\mathbf{4}$ in enantiopure form has been demonstrated, and further studies are underway.

\section{Experimental Section}


General Procedures. The baker's yeast used was Saccharomyces cerevisiae Type II, Sigma product YSC-2, antifoam refers to Antifoam 289; Sigma product A-5551. The chemicals used as additives were commercial materials used without purification. All the procedures were carried out using tap water, and unless otherwise stated were conducted in a reciprocal shaker thermostatted at $28{ }^{\circ} \mathrm{C}$. The immobilised baker's yeast was prepared according to an established procedure. ${ }^{11,15}$ Commercial $m$-CPBA was purified following the procedure described in ref. 17. Proton and ${ }^{13} \mathrm{C}$ NMR spectra were recorded at 300 and $75 \mathrm{MHz}$ respectively, chemical shifts are quoted in ppm relative to tetramethylsilane and coupling constants are given in $\mathrm{Hz}$. The concentrations of optical rotation samples are quoted in $\mathrm{g} / 100 \mathrm{~mL}$.

2-(Carboethoxymethylthio)cyclohexanone (10). ${ }^{10}$ A solution of ethyl mercaptoacetate $(2.49 \mathrm{~g}$, $2.3 \mathrm{~mL} 20.7 \mathrm{mmol}), \mathrm{Et}_{3} \mathrm{~N}(2.10 \mathrm{~g}, 2.90 \mathrm{~mL}, 20.7 \mathrm{mmol})$ and 2-chlorocyclohexanone (2.5 g, $18.9 \mathrm{mmol})$ in $\mathrm{CH}_{2} \mathrm{Cl}_{2}(25 \mathrm{~mL})$ was stirred for $2 \mathrm{~h}$ at ambient temperature. The mixture was diluted with $\mathrm{CH}_{2} \mathrm{Cl}_{2}$, washed twice with $2 \mathrm{M} \mathrm{HCl}$, twice with saturated $\mathrm{NaHCO}_{3}$ and once with brine. The organic layer was dried over $\mathrm{MgSO}_{4}$ and concentrated to afford 10 (4.02 $\mathrm{g}$, quantitative yield) as a pale oil which was pure enough to use directly. $\delta_{\mathrm{H}}\left(\mathrm{CDCl}_{3}\right) 1.28(\mathrm{t}, \mathrm{J}=$ 7.1, $3 \mathrm{H}, \mathrm{CH}_{2} \mathrm{CH}_{3}$ ), 1.70-2.05 (m, $5 \mathrm{H}$, cyclohexyl ring), 2.17-2.35 (m, $2 \mathrm{H}$, cyclohexyl ring), 2.82-2.95 (m, $1 \mathrm{H}$, cyclohexyl ring), 3.26 (apparent q, J = 15.4, $2 \mathrm{H}, \mathrm{SCH}_{2}$ ), 3.56-3.61 (m, $1 \mathrm{H}$, CHS), $4.18\left(\mathrm{q}, \mathrm{J}=7.1,2 \mathrm{H}, \mathrm{CH}_{2} \mathrm{CH}_{3}\right) ; \delta_{\mathrm{C}}\left(\mathrm{CDCl}_{3}\right)$ 14.1, 22.4, 26.9, 32.9, 33.1, 38.4, 52.4, 61.5, 170.0, 207.5.

\section{Baker's yeast reductions}

Procedure A. High yeast concentration (Table 1, entry 1). The procedure is adapted from that of Ridley. ${ }^{13}$ A mixture of baker's yeast (10 g), sucrose (10 g) and antifoam (2-3 drops) in water $(60 \mathrm{~mL})$ was incubated for $30 \mathrm{~min}$, after which compound 10 (100 mg), dissolved in DMSO $(1 \mathrm{~mL})$ was added and shaking was continued. After $24 \mathrm{~h}$, Celite ${ }^{\circledR}(c a .5 \mathrm{~g})$ was added and after $30 \mathrm{~min}$, the mixture was filtered. The filter cake was washed with two portions of EtOAc $(40 \mathrm{~mL})$, the filtrate was separated and the aqueous layer was extracted with EtOAc $(4 \times 40 \mathrm{~mL})$. The combined organic phases were washed with water $(50 \mathrm{~mL})$ and brine $(50 \mathrm{~mL})$, dried over $\mathrm{MgSO}_{4}$ and concentrated. The residue was taken up in $\mathrm{CHCl}_{3}(10 \mathrm{~mL})$, a flake of tosic acid was added and the resulting mixture heated at reflux temperature for $3 \mathrm{~h}$. The solvent was removed, the residue filtered twice though a plug of $\mathrm{SiO}_{2}$ and the residue examined by HPLC to reveal the presence of $12(78 \%, \geq 98 \%$ ee) and $13(22 \%, \geq 98 \%$ ee $)$

Procedure B. Low yeast concentration (Table 1, entry 2). The procedure is adapted from that of Seebach. ${ }^{14}$ A mixture of baker's yeast $(130 \mathrm{mg})$ and sugar $(0.98 \mathrm{~g})$ in water $(40 \mathrm{~mL})$ was incubated for $30 \mathrm{~min}$, after which compound $10(65 \mathrm{mg})$ in DMSO (1 mL) was added. After shaking for $60 \mathrm{~h}$, second portions of yeast $(130 \mathrm{mg})$ and sugar $(650 \mathrm{mg})$ were added, followed $1 \mathrm{~h}$ later by a second portion of substrate $(65 \mathrm{mg})$. After a further $48 \mathrm{~h}$, Celite ${ }^{\circledR}$ (ca. $5 \mathrm{~g}$ ) was added, and the reaction was worked up as described above in procedure A. The crude product was purified by dry flash chromatography (4:1 hexanes-EtOAc, working over to EtOAc with 5\% 
gradient) to afford $25 \mathrm{mg}(24 \%)$ of a mixture of 12 and 13. HPLC analysis revealed $59 \% 12$ ( $\geq$ 98\% ee) and $41 \% 13$ (66\% ee).

Procedure C. Immobilised baker's yeast (Table 1, entry 3). Beads of Immobilised baker's yeast $(100 \mathrm{~mL}$, ca $10 \mathrm{~g}$ yeast content) were placed in hexanes $(100 \mathrm{~mL})$ and $\mathrm{MeOH}(1 \mathrm{~mL})$ was added. The mixture was incubated for $30 \mathrm{~min}$, whereupon compound $\mathbf{1 0}$ (100 mg) was added. After five days of shaking, the mixture was filtered and the beads washed with hexanes $(3 \times$ $25 \mathrm{~mL}$ ). After conventional aqueous workup, the isolated material (74 $\mathrm{mg}$ ) was determined by TLC and ${ }^{1} \mathrm{H}$ NMR analysis to be unreacted starting material (74\% recovery).

Procedure D. Free baker's yeast in ether (Table 1, entry 4). A mixture of yeast (10 g) and 10 $(100 \mathrm{mg})$ in $\mathrm{Et}_{2} \mathrm{O}(50 \mathrm{~mL})$ in a covered flask was shaken for $48 \mathrm{~h}$ at $28^{\circ} \mathrm{C}$. Celite ${ }^{\circledR}(\mathrm{ca} .5 \mathrm{~g})$ was added, the mixture was diluted with brine $(50 \mathrm{~mL})$ and filtered. The filtrate was separated, the organic layer dried over $\mathrm{MgSO}_{4}$ and concentrated. TLC and ${ }^{1} \mathrm{H}$ NMR analysis revealed no reaction.

Reduction in the presence of allyl alcohol (Table 1, entry 5). The reaction was carried out according to the general procedure A with the exception that allyl alcohol $(240 \mu \mathrm{L})$ was added before the incubation period. After $24 \mathrm{~h}$ of reaction, usual workup and cyclisation followed by dry flash chromatography afforded $17 \mathrm{mg}$ (19\%) of the mixed lactones, which was shown by HPLC analysis to be $77 \%$ cis- ( $97 \%$ ee) and $23 \%$ trans- $(\geq 98 \%$ ee).

Reduction in the presence of methyl vinyl ketone (Table 1, entry 6). The reaction was carried out according to the general procedure A with the exception that methyl vinyl ketone $(300 \mu \mathrm{L})$ was added before the incubation period, and the mixture was incubated for 60 minutes. After $24 \mathrm{~h}$ the reaction was worked up and subjected to the cyclisation conditions described above. Analysis by TLC and ${ }^{1} \mathrm{H}$ NMR revealed a complex mixture of products, none of the desired material was present.

Reduction in the presence of ethyl chloroacetate (Table 1, entry 7). The reaction was carried out according to the general procedure A with the exception that ethyl chloroacetate $(385 \mu \mathrm{L})$ was added before the incubation period. After $24 \mathrm{~h}$ the reaction was worked up and subjected to the cyclisation conditions described above. Analysis by TLC and ${ }^{1} \mathrm{H}$ NMR revealed a complex mixture of products which did not contain any of the desired material.

Reduction in the presence of ethyl bromoacetate (Table 1, entry 8). The reaction was carried out according to the general procedure A with the exception that ethyl bromoacetate (400 $\mu \mathrm{L})$ was added before the incubation period. After $24 \mathrm{~h}$ the reaction was worked up and subjected to the cyclisation conditions described above. Analysis by TLC and ${ }^{1} \mathrm{H}$ NMR revealed a complex mixture of products, none of the desired material was present.

Low-yeast reduction in the presence of allyl alcohol (Table 1, entry 9). The reaction was carried out according to the general procedure B with the exception that allyl alcohol ( $25 \mu \mathrm{L})$ was added before the incubation period. After $24 \mathrm{~h}$ the reaction was worked up as before. Analysis by TLC and ${ }^{1} \mathrm{H}$ NMR revealed only unreacted starting material.

Reduction with increased concentration of substrate (Table 1, entry 10). The reaction was carried out according to procedure A with the exception that $0.5 \mathrm{~g}$ of $\mathbf{1 0}$ was used. Proton NMR 
analysis of the material obtained after workup and cyclisation revealed roughly $20 \%$ conversion. The crude material was twice passed through a plug of $\mathrm{SiO}_{2}$ and examined by HPLC revealing $87 \% 12$ ( $\geq 98 \%$ ee) and $13 \% 13$ ( $\geq 98 \%$ ee).

Reduction with procedure A on increased scale (Table 1, entry 11). A 2 L conical flask was charged with baker's yeast (100 g), sugar (100 g), tap water (600 mL) and antifoam (10 drops), and placed in a glycerol bath pre-equilibrated and maintained at $29 \pm 1{ }^{\circ} \mathrm{C}$ by means of a contact thermometer. After $30 \mathrm{~min}$. incubation with gentle stirring, the substrate $\mathbf{1 0}$ (1.0 g, $4.62 \mathrm{mmol})$ was added and stirring was continued over three nights. Celite ${ }^{\circledR}$ (ca $50 \mathrm{~mL}$ ) was added and after $30 \mathrm{~min}$. further stirring, the mixture was filtered. The filter cake was washed with EtOAc $(3 \times$ $200 \mathrm{~mL})$ and once with $\mathrm{Et}_{2} \mathrm{O}(200 \mathrm{~mL})$, the filtrate was separated and the aqueous phase extracted three times with EtOAc $(3 \times 200 \mathrm{~mL})$. The combined organic layers were washed with brine $(3 \times 200 \mathrm{~mL})$, dried over $\mathrm{MgSO}_{4}$ and evaporated. The residue was taken up in $\mathrm{CHCl}_{3}(\mathrm{ca}$ $30 \mathrm{~mL}$ ), three flakes of $\mathrm{TsOH}$ were added and the mixture was heated under reflux for $3 \mathrm{~h}$. The solvent was removed and the residue purified by dry flash chromatography to afford $111 \mathrm{mg}$ $(12 \%)$ of product which was shown by HPLC analysis to be $78 \% 12$ ( $\geq 98 \%$ ee) and 22\% 13 ( $\geq 98 \%$ ee).

Reduction using procedure $B$ on preparative scale (Table 1, entry 12). The reaction was carried out following procedure B using $1 \mathrm{~g}$ of $\mathbf{1 0}$ which was split between five conical flasks containing yeast $(200 \mathrm{mg})$, sugar $(1.5 \mathrm{~g})$ and water $(80 \mathrm{~mL})$ and which were incubated in the usual way. The reaction vessels were shaken gently for two days then treated with further portions of yeast and sugar. After a further two days, second portions of yeast $(200 \mathrm{mg})$ and sugar $(1.5 \mathrm{~g})$ were added and shaking was continued two days more. The contents of the flasks were combined together and worked up and cyclised as before. The yield of product was $188 \mathrm{mg}$ ( $25 \%$ ), shown by HPLC to be $47 \%$ cis- ( $\geq 98 \%$ ee) and $53 \%$ trans- (76\% ee). Further purification by repeated flash chromatography (4:1 hexanes/EtOAc) afforded $30 \mathrm{mg}(4 \%)$ of pure 12 as a colourless solid. $\delta_{\mathrm{H}}\left(\mathrm{CDCl}_{3}\right)$ 1.20-1.39 (m, $1 \mathrm{H}$, cyclohexyl ring), 1.54-1.78 (m, $6 \mathrm{H}$, cyclohexyl ring), 2.16-2.20 (m, $1 \mathrm{H}$, cyclohexyl ring), 3.18 (A part of $\mathrm{ABq}, \mathrm{J}=14.5,1 \mathrm{H}$, one of $\mathrm{SCH}_{2}$ ), 3.17-3.21 (m, $1 \mathrm{H}, \mathrm{SCH}), 3.57\left(\mathrm{~B}\right.$ part of $\mathrm{ABq}, \mathrm{J}=14.5,1 \mathrm{H}$, one of $\left.\mathrm{SCH}_{2}\right), 4.56-4.59(\mathrm{~m}, 1 \mathrm{H}$, $\mathrm{OCH}) ; \delta_{\mathrm{C}}\left(\mathrm{CDCl}_{3}\right) 19.3,25.0,25.7,30.8,30.9,39.7,76.3,168.5 ;$ m.p. $58-59{ }^{\circ} \mathrm{C} ;[\alpha]_{\mathrm{D}}{ }^{22}-102^{\circ}$ (c $\left.=1.02, \mathrm{CHCl}_{3}\right)$.

Reduction using procedure $B$ on preparative scale with modified workup (Table 1, entry 13). The reduction reaction was carried out as described above for entry 12. After reaction completion was determined by TLC the water was decanted from the yeast residue and extracted with ether. The organic layer was dried $\left(\mathrm{MgSO}_{4}\right)$ and concentrated under reduced pressure to give the crude product as a colourless oil. This first extraction afforded $700 \mathrm{mg}$ of the crude. Ether was then added to the remaining slurry in the conical flasks and this mixture was filtered to remove the yeast residue. The filtrate was separated and the organic layer was dried $\left(\mathrm{MgSO}_{4}\right)$ and concentrated under reduced pressure to give a further $200 \mathrm{mg}$ of crude product as a colourless oil. The combined crude products were purified by flash chromatography (4:1 hexanes/ethyl acetate) to give the mixed hydroxy esters $\mathbf{1 1}$ and $\mathbf{1 4}$ as a colourless oil (450 mg, 
$45 \%) \delta_{\mathrm{H}}\left(\mathrm{CDCl}_{3}\right) 1.29\left(\mathrm{t}, \mathrm{J}=7,3 \mathrm{H}, \mathrm{CH}_{3}\right), 1.34-2.67(\mathrm{~m}, 9 \mathrm{H}$ cyclohexyl ring and $\mathrm{OH}), 3.01-$ 3.08 (m, $1 \mathrm{H}, \mathrm{CHS}), 3.19-3.38$ (ABq, J = 15.3, 2 H, $\mathrm{SCH}_{2}$ ), 3.84-3.87 (m, $\left.1 \mathrm{H}, \mathrm{CHO}\right), 4.20$ (q, J $\left.=7,2 \mathrm{H}, \mathrm{CH}_{2} \mathrm{CH}_{3}\right)$.

Cyclisation of the hydroxy esters. Bicyclic sulfides $(5 R, 6 S)$-cis-hexahydro-1,4-benzoxathiin2(3H)-one 12 and (5S,6S)-trans-hexahydro-1,4-benzoxathiin-2(3H)-one (13). The procedure is essentially that described by Vankar. ${ }^{10}$ The hydroxy ester $(200 \mathrm{mg} 0.92 \mathrm{mmol})$ was dissolved in benzene $(5 \mathrm{~mL})$ and $\mathrm{TsOH}(9 \mathrm{mg} 0.047 \mathrm{mmol})$ was added. The reaction mixture was heated under reflux for 15 min using a Dean-Stark trap. The reaction mixture was cooled and washed with water $(1 \mathrm{~mL})$, the organic layer was separated, dried over $\mathrm{MgSO}_{4}$ and concentrated to give a brown oil. Repeated purification by column chromatography (4:1 hexanes/ethyl acetate) gave 12 (60 mg, 32\% $\geq 98 \%$ ee), and $13\left(20 \mathrm{mg}, 10 \% \geq 98 \%\right.$ ee) $\delta_{\mathrm{H}}\left(\mathrm{CDCl}_{3}\right) 1.27-2.28(\mathrm{~m}, 8 \mathrm{H}$, cyclohexyl ring), 2.96-3.05 (m, $1 \mathrm{H}, \mathrm{CHS}), 3.23,3.69$ (ABq, J = 14.6, $\left.2 \mathrm{H}, \mathrm{SCH}_{2}\right), 4.13-4.18$ (m, $1 \mathrm{H}, \mathrm{CHO}) ; \delta_{\mathrm{C}}\left(\mathrm{CDCl}_{3}\right) 23.7,251,26.8,32.2,32.63,43.07,81.6,168.1 ;[\alpha]_{\mathrm{D}}{ }^{19}-189^{\circ}(\mathrm{c}=0.95$, $\mathrm{CHCl}_{3}$ ); mp 87.5-88.5 (lit. ${ }^{18} 88-89{ }^{\circ} \mathrm{C}$ ).

$(4 R, 5 R, 6 S)-(-)$-cis-Hexahydro-1,4-benzoxathiin-2(3H)-one-S-oxide (1). A solution of $m$ CPBA (25 mg, $0.14 \mathrm{mmol})$ in dichloromethane $(5 \mathrm{ml})$ was added to a stirring solution of 12 $(25 \mathrm{mg}, 0.14 \mathrm{mmol})$ in dichloromethane $(15 \mathrm{ml})$ at $0{ }^{\circ} \mathrm{C}$. The reaction mixture was stirred at $0{ }^{\circ} \mathrm{C}$ for $3 \mathrm{~min}$. The mixture was then filtered and the dichloromethane solution washed with cold with $10 \% \mathrm{NaHCO}_{3}(2 \times 5 \mathrm{ml})$. The organic layer was dried $\left(\mathrm{MgSO}_{4}\right)$ and concentrated under reduced pressure to give the crude product as a white solid. The white solid was recrystallised from dichloromethane/hexane slowly at room temperature to give the pure cis-sulfoxide $\mathbf{1}$ as a single diastereomer $(15 \mathrm{mg}, 55 \%)$. HPLC analysis revealed $\left(\geq 98 \%\right.$ ee). $[\alpha]_{\mathrm{D}}{ }^{21}-17\left(\mathrm{c}=0.7, \mathrm{CHCl}_{3}\right)$; $\cup_{\max }(\mathrm{NaCl}) / \mathrm{cm}^{-1} 1732(\mathrm{C}=\mathrm{O}), 1051(\mathrm{~S}=\mathrm{O}) ; \delta_{\mathrm{H}}\left(\mathrm{CDCl}_{3}\right)$ 1.18-2.21 (8H, m, cyclohexyl ring), 2.83-2.89 (1H, m, CHS), 3.44-3.49, 3.98-4.04 (2H, ABq, J = 16, $\left.\mathrm{SOCH}_{2} \mathrm{CO}\right), 5.26-5.34$ (1H, br $\mathrm{s}, \mathrm{CHO}) ; \delta_{\mathrm{C}}\left(\mathrm{CDCl}_{3}\right)$ 18.23, 21.52, 24.83, $30.45\left(4 \times \mathrm{CH}_{2}\right.$, cyclohexyl ring), $49.29\left(\mathrm{CH}_{2}\right.$, $\left.\mathrm{SOCH}_{2} \mathrm{CO}\right) 59.26(\mathrm{CH}, \mathrm{CHS}), 71.46(\mathrm{CH}, \mathrm{CHO}), 163.58(\mathrm{C}=\mathrm{O})$.

$\mathbf{( 4 S , 5 R , 6 S ) - ( + ) - c i s - H e x a h y d r o - 3 - d i a z o - 1 , 4 - b e n z o x a t h i i n - 2 ( 3 H ) - o n e - S - o x i d e ~ ( 4 ) . ~ T r i e t h y l a m i n e ~}$ $(10 \mu \mathrm{L}, 0.08 \mathrm{mmol})$ was added to a stirring solution of $1(15 \mathrm{mg}, 0.08 \mathrm{mmol})$ in acetonitrile (10 $\mathrm{ml})$. Tosyl azide $(15 \mathrm{mg}, 0.08 \mathrm{mmol})$ was then added dropwise at $0{ }^{\circ} \mathrm{C}$ and the solution was stirred overnight while slowly returning to room temperature. The mixture was concentrated under reduced pressure to give the crude product as an orange oil. Purification by flash chromatography (3:2 hexanes/ethyl acetate) gave the pure cis-diazosulfoxide 4 as a yellow crystalline solid (7 mg, 41\%); mp 112-114 ${ }^{\circ} \mathrm{C}$ (blackened $104-108{ }^{\circ} \mathrm{C}$ ). HPLC analysis revealed $\geq 98 \%$ ee. $[\alpha]_{\mathrm{D}}^{21}+40^{\circ}\left(\mathrm{c}=0.6, \mathrm{CHCl}_{3}\right)$; (Found: $\mathrm{C}, 44.81 ; \mathrm{H}, 4.83 ; \mathrm{N}, 13.15 ; \mathrm{S}, 14.55$; $\mathrm{C}_{8} \mathrm{H}_{10} \mathrm{~N}_{2} \mathrm{O}_{3} \mathrm{~S}$ requires $\left.\mathrm{C}, 44.85 ; \mathrm{H}, 4.70 ; \mathrm{N}, 13.08 ; \mathrm{S}, 14.96 \%\right) ; \mathrm{v}_{\max }(\mathrm{KBr}) / \mathrm{cm}^{-1} 2128\left(\mathrm{C}=\mathrm{N}_{2}\right)$, $1681(\mathrm{C}=\mathrm{O}) ; \delta_{\mathrm{H}}\left(\mathrm{CDCl}_{3}\right)$ 1.25-1.76 $\left(5 \mathrm{H}, \mathrm{m}\right.$, cyclohexyl ring), 1.92-1.96 (2H, br d, $\mathrm{CH}_{2}$ cyclohexyl ring), 2.29-2.41 (1H, br d, $\left.\mathrm{CH}_{2}\right), 2.94-2.99(1 \mathrm{H}$, ddd, J = 2, 3, 13, CHS), 5.35-5.41 $(1 \mathrm{H}$, br s, $\mathrm{CHO}) ; \delta_{\mathrm{C}}\left(\mathrm{CDCl}_{3}\right)$ 19.07, 20.10, 24.57, $31.01\left(4 \times \mathrm{CH}_{2}\right), 58.76(\mathrm{CHS}), 69.84(\mathrm{CHO})$, $159.27(C=\mathrm{O}) ; \mathrm{m} / \mathrm{z} 214\left(\mathrm{M}^{+}\right)$. 
Table 2. Chiral HPLC data

\begin{tabular}{|c|c|c|}
\hline Compound & Column/Conditions ${ }^{\mathrm{a}}$ & Retention times/min \\
\hline \multirow{2}{*}{12} & AS & $15.1[(5 R, 6 S)-(-)-($ cis- $)]$ \\
\hline & $20{ }^{\circ} \mathrm{C}, 30 \%$ IPA in hexane & $57.5[(5-S, 6-R)-(+)-($ cis- $)]$ \\
\hline \multirow{2}{*}{13} & AS & $22.9[(5 S, 6 S)-(-)-($ trans- $)]$ \\
\hline & $20{ }^{\circ} \mathrm{C}, 30 \%$ IPA in hexane & $41.6[(5 R, 6 R)-(+)-($ trans- $)]$ \\
\hline \multirow{2}{*}{1} & $\mathrm{AD}$ & $6.1[(4 S, 5 S, 6 R)-(+)-($ cis- $)]$ \\
\hline & Ambient, $60 \%$ IPA in hexane & $14.4[(4 R, 5 R, 6 S)-(-)-($ cis- $)]$ \\
\hline \multirow{2}{*}{4} & $\mathrm{AD}$ & $11.1[(4 R, 5 S, 6 R)-(-)-($ cis- $)$ \\
\hline & Ambient, $20 \%$ IPA in hexane & $15.1[4 S, 5 R, 6 S)-(+)-($ cis- $)]$ \\
\hline
\end{tabular}

a. Columns: Chiralpak AS $0.46 \times 25 \mathrm{~cm}$, Chiralpak AD. $0.46 \times 25 \mathrm{~cm}$; Flow rates $1.0 \mathrm{~mL} / \mathrm{min}$, detector wavelength $220 \mathrm{~nm}$.

\section{Acknowledgements}

Financial support from Enterprise Ireland, Pfizer Ireland Pharmaceuticals, and BioResearch Ireland is gratefully acknowledged. We also wish to thank Johnson Matthey for a loan of rhodium acetate and B. O'Donovan (UCC) for provision of the immobilized baker's yeast used in this work.

\section{References}

1. (a) Regitz, M.; Maas, G. Diazo Compounds, Properties and Synthesis, Academic Press: London, 1986. (b) Regitz, M. Angew. Chem., Int. Ed. Engl. 1967, 6, 743. (c) Regitz, M. Synthesis, 1972, 351.

2. Hodson, D.; Holt, G. J. Chem. Soc. (C) 1968, 1602.

3. Maguire, A. R.; Kelleher, P. G.; Ferguson, G.; Gallagher, J. F. Tetrahedron Lett. 1998, 39, 2819.

4. Maguire, A. R.; Kelleher, P. G.; Lawrence, S. E. Tetrahedron Lett. 1998, 39, 3849.

5. Sander, W., Strehl, A.; Maguire, A. R.; Collins, S.; Kelleher, P. G. Eur. J. Org. Chem. 2000, 3329.

6. (a) Servi, S. Synthesis 1990, 1. (b) Csuk, R.; Glanzer, B. I. Chem. Rev. 1991, 91, 49. (c) Sato, T.; Fujisawa, T. Biocatalysis 1990, 3, 1. (d) Roberts, S. M. J. Chem. Soc., Perkin Trans. 1 1999, 1.

7. (a) Maguire, A. R.; Kelleher, L. L.; Ferguson, G. J. Mol. Catalysis B: Enzymatic 1996, 1, 115. (b) Maguire, A. R.; Kelleher, L. L. Tetrahedron Lett. 1997, 38, 7459. (c) Maguire, A. R.; Lowney, D. G. J. Chem. Soc., Perkin Trans. 1 1997, 235. 
8. Maguire, A. R.; O’ Riordan, N. Tetrahedron Lett. 1999, 40, 9285.

9. Fujisawa, T.; Yamanaka, K.; Mobele, B. I.; Shimizu, M. Tetrahedron Lett. 1991, 32, 399.

10. Vankar, Y. D.; Shah, K.; Bawa, A.; Singh, S. P. Tetrahedron 1991, 47, 8883.

11. (a) Nakamura, K. Microbial Reagents in Organic Synthesis, Servi, S., Ed.; Kluwer Academic Publishers: Dordrecht 1991; 389. (b) Nakamura, K.; Kawai, Y.; Ohno, A., Tetrahedron Lett. 1991, 32, 2927. (c) Nakamura, K.; Kawai, Y.; Nakajima, N.; Ohno, A., J. Org. Chem. 1991, 56, 4778. (d) Nakamura, K.; Kawai, Y.; Oka, S.; Ohno, A. Tetrahedron Lett. 1989, 30, 2245. (e) Nakamura, K.; Kawai, Y.; Miyai, T.; Ohno, A. Tetrahedron Lett. 1990, 31, 3631. (f) Kawai, Y.; Kondo, S. I.; Tsujimoto, M.; Nakamura, K.; Ohno, A., Bull. Chem. Soc. Jpn. 1994, 67, 2244. (g) Klibanov, A. M. Acc. Chem. Res. 1990, 23, 114. (h) Nakamura, K.; Inoue, K.; Ushio, K.; Oka, S.; Ohno, A. Chem. Lett. 1987, 697.

12. Presumably in the work in reference 10 both isomers were also formed but only $\mathbf{1 3}$ was recovered following purification.

13. Crumbie, R. J.; Doel, B. S.; Nemorin, J. E.; Ridley, D. D. Aust. J. Chem. 1978, 31, 1965.

14. Seebach, D.; Sutter, M. A.; Weber, R.; Zuger, M. Org. Synth. 1984, 63, 1.

15. (a) Takeda, A.; Sakai, T.; Nakamura, T.; Fukuda, K.; Amano, E.; Utaka, M. Bull. Chem. Soc. Japan 1986, 59, 3185. (b) Boyes, A. Preparative Biotransformations, Roberts, S. M., Ed.; Wiley-Interscience: Chichester, 1994, section 2:9.1.

16. (a) Rotthaus, O.; Kruger, D.; Demuth, M.; Schaffner, K. Tetrahedron 1997, 53, 935. (b) North, M. Tetrahedron Lett. 1996, 37, 1699.

17. Fieser, L. F.; Fieser, M. Reagents for Organic Synthesis, Wiley: New York, 1967; 1, p. 135.

18. Koskimies, J. K. Acta Chem. Scand., Ser. B 1981, 38, 101. 